
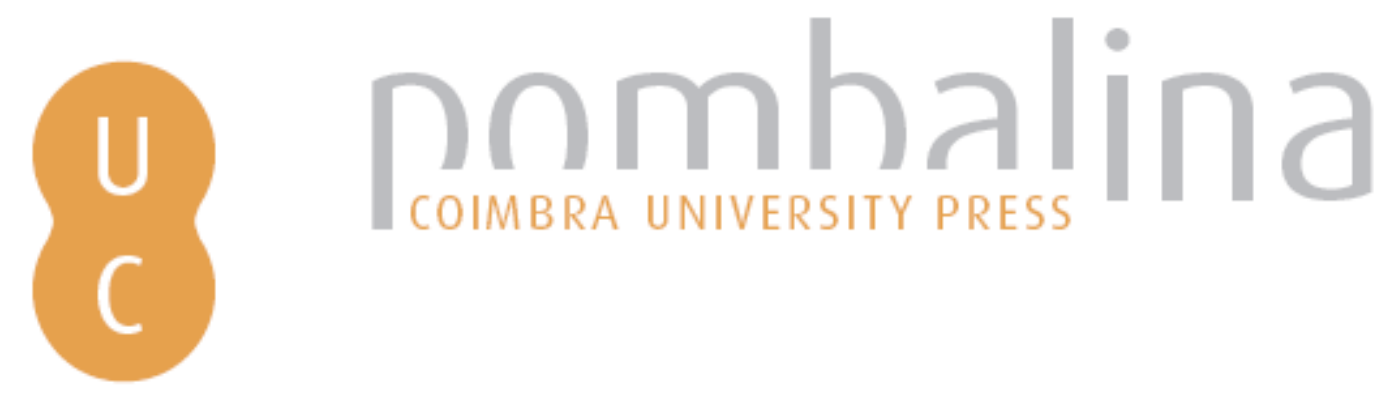

\title{
Rural abandonment and landscape evolution in the central region of Portugal
}

Autor(es): $\quad$ Almeida, António Campar de

Publicado por: Imprensa da Universidade de Coimbra

URL

persistente:

URI:http://hdl.handle.net/10316.2/30542

DOI:

DOI:http://dx.doi.org/10.14195/978-989-26-0317-9_2

Accessed : $\quad$ 26-Apr-2023 15:20:14

A navegação consulta e descarregamento dos títulos inseridos nas Bibliotecas Digitais UC Digitalis, UC Pombalina e UC Impactum, pressupõem a aceitação plena e sem reservas dos Termos e Condições de Uso destas Bibliotecas Digitais, disponíveis em https://digitalis.uc.pt/pt-pt/termos.

Conforme exposto nos referidos Termos e Condições de Uso, o descarregamento de títulos de acesso restrito requer uma licença válida de autorização devendo o utilizador aceder ao(s) documento(s) a partir de um endereço de IP da instituição detentora da supramencionada licença.

Ao utilizador é apenas permitido o descarregamento para uso pessoal, pelo que o emprego do(s) título(s) descarregado(s) para outro fim, designadamente comercial, carece de autorização do respetivo autor ou editor da obra.

Na medida em que todas as obras da UC Digitalis se encontram protegidas pelo Código do Direito de Autor e Direitos Conexos e demais legislação aplicável, toda a cópia, parcial ou total, deste documento, nos casos em que é legalmente admitida, deverá conter ou fazer-se acompanhar por este aviso. 


\section{REGIONAL}

AND LOCAL

RESPONSES

\section{IN PORTUGAL}

\section{IN THE CONTEXT OF}

MARGINALIZATION

\section{AND GLOBALIZATION}

FERNANDA CRAVIDÃO

LÚCO GUNHA

NORBERTO PINTO DOS SANTOS

COORDENACÃO

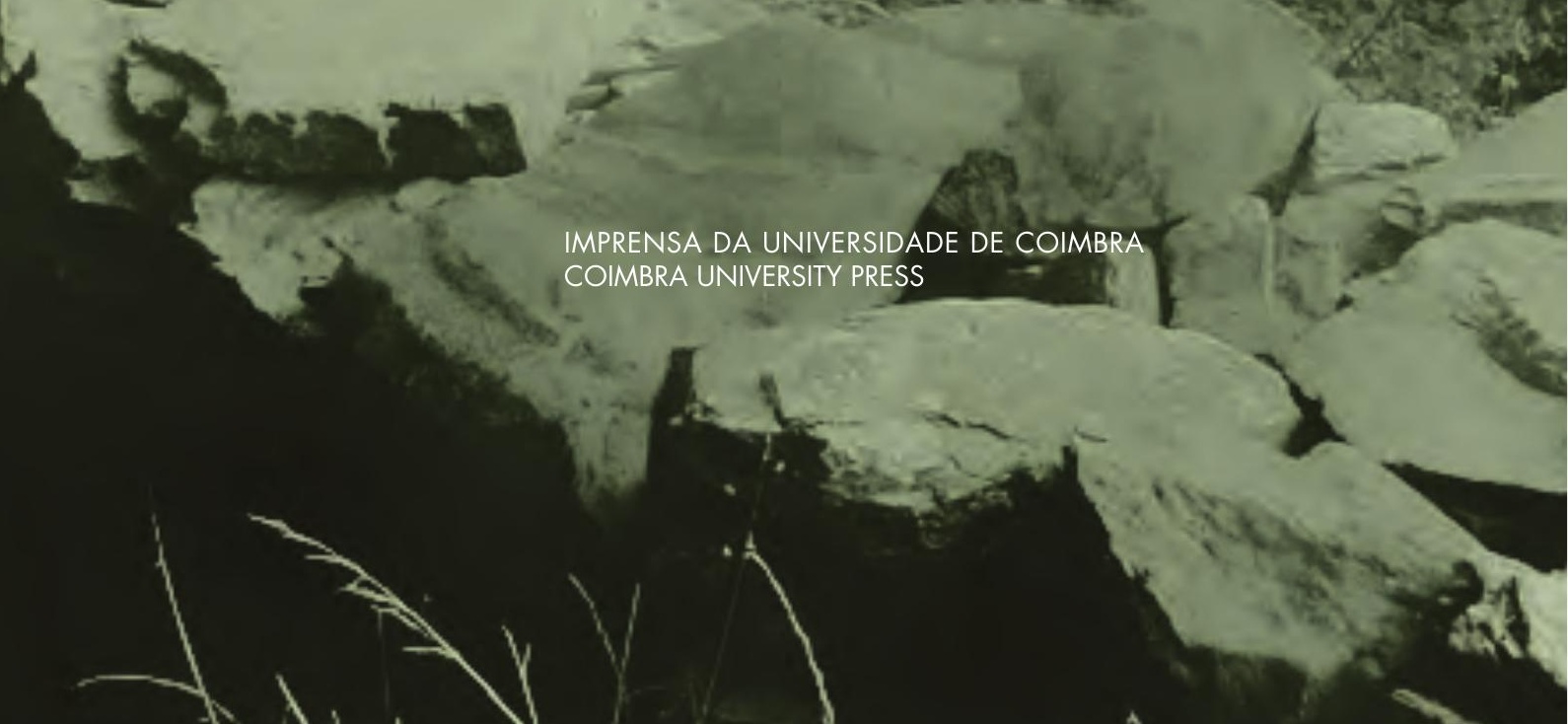




\section{Rural abandonment and LANDSCAPE EVOLUtion in the Central Region of Portugal ${ }^{1}$}

The landscapes of countries such as European ones, whose territories have long been occupied and used by groups of humans in different stages of development and organisation, are essentially a product of History, just as Georges Bertrand (1978) said. Even when, under specific circumstances, human communities cease to occupy parts of a territory and abandon it to nature, the result of its evolution can never be identified as though it was virgin landscape. The changes of morphology, the transformation of the soil, the introduction of new species, some of which could be seen as invaders, or at least as being highly adaptable, the existing infrastructures, etc, are marks which will only disappear from those landscapes with difficulty.

The level of human intervention in Portuguese rural landscapes and, in this specific case, in the Central Region² (Fig. 1), increased until the middle of the $20^{\text {th }}$ century and then it decreased significantly because of the profound demographic changes in the last few decades. The diversity of the socioeconomic dynamics that operated in the different sub-regions had distinct effects on those landscapes and this work will try to show these effects. Several important indicators are used but the results will nonetheless be incomplete.

\footnotetext{
${ }^{1}$ Work financed by Fundação para a Ciência e Tecnologia and FEDER through the project POCTI/GEO/49371/2002

${ }^{2}$ In terms of agriculture and forest the Central Region is subdivided into the Região Agrária da Beira Litoral (Baixo Vouga, Baixo Mondego, Pinhal Litoral, Dão-Lafões and Pinhal Interior Norte) and the Região Agrária da Beira Interior (Pinhal Interior Sul, Serra da Estrela, Beira Interior Norte, Beira Interior Sul and Cova da Beira).
} 
The socio-economic data is based on the analysis of official Portuguese statistics for the Central Region, particularly on the population censuses of 1970, 1981, 1991 and 2001 and on the agriculture censuses of 1968, 1979, 1989 and 1999. Aerial photographs taken in 1958 and 1995 in some sample areas, which should represent the broadest diversity possible of the whole of the region, were compared to detect and illustrate the changes in terms of the occupation of the soil.

Before showing these changes, though, one should look at some social and economic indicators which will easily help understand the changes that have occurred and the prospects, in terms of the landscape, for this region.

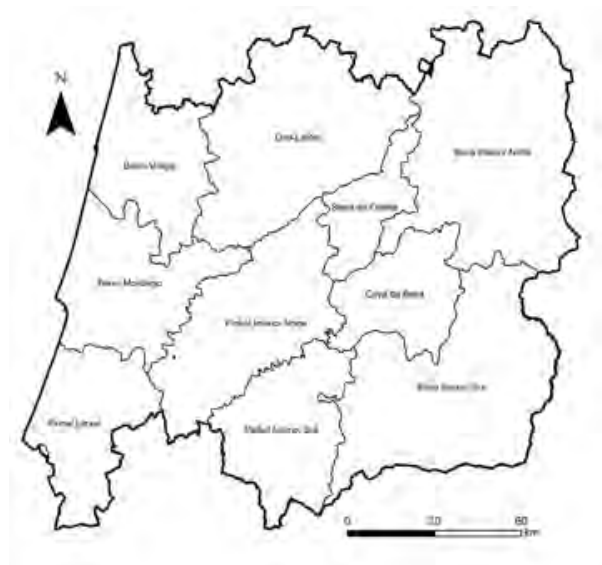

Fig. 1 - Central Region of Portugal and its Sub-regions

\section{1 - Some noticeable socio-economic changes}

\section{a) Sectors of activity}

In 2001 the tertiary was the largest sector in the region (Fig. 2), and here Baixo Mondego stands out. This is partly because of Coimbra, a city of services, but it is also because the industry is not significant in other inland cities. In Baixo Vouga and Pinhal Litoral, on the contrary, the industrial sector is almost as important as the service sector. Obviously the primary 
sector, which is essentially confined to agro forestry, engages a small percentage of the population - only 5\% in coastal sub-regions and 10\% in inland sub-regions such as Beira Interior Sul, Beira Interior Norte and Dão-Lafões.

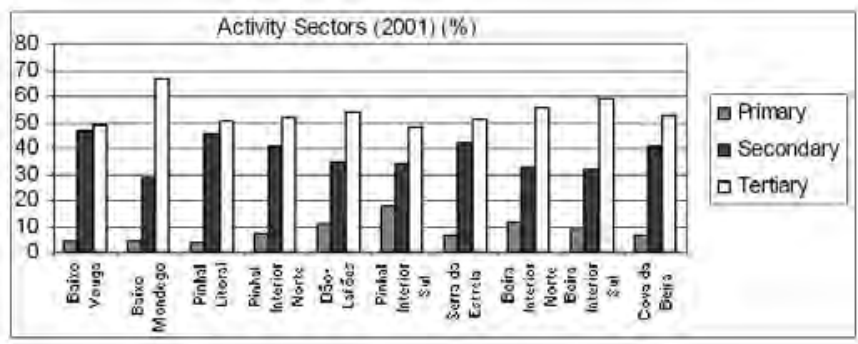

Fig. 2 - Activity sectors in 2001 (Source: INE)

In the last few decades this sector has seen a sharp decline throughout the region. In 1970 this region was essentially rural, just like most of the country, occupying an average of about $60 \%$, and always more than $42 \%$, of the active population. Three decades later the average is below 10\% (Fig. 3).

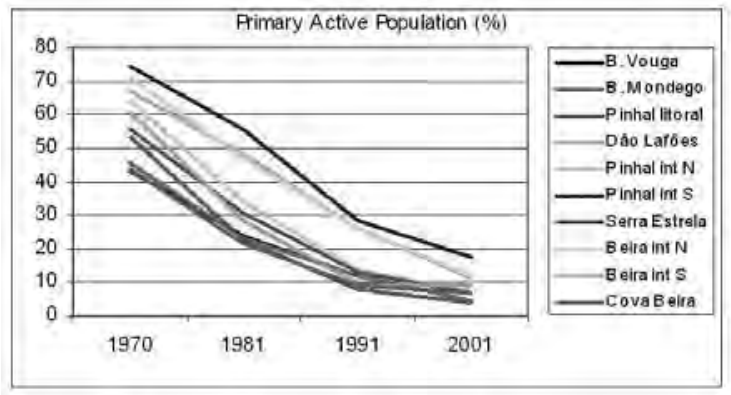

Fig. 3 - Active population in primary sector (Source: INE)

\section{b) Resident population variation}

The resident population is essentially concentrated in the region's littoral and this can be seen by the population density of the sub-regions (higher 
than 144 inhabitants $/ \mathrm{km}^{2}$ in the littoral sub-regions and just over 20 inhabitants $/ \mathrm{km}^{2}$ in the inland regions), i.e., it varies from 10 in the littoral to 1 inland (Fig. 4). This discrepancy increased from 1991 to 2001 with a decrease inland and an increase in the littoral (Fig. 5).

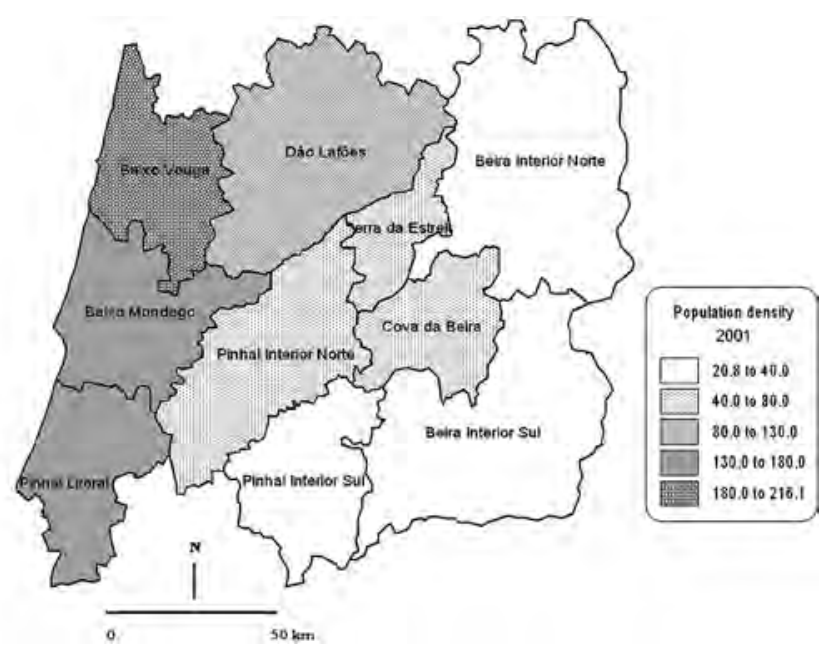

Fig. 4 - Population density in 2001 (Source: INE)

One of the demographic processes that helps understand this discrepancy is inter-municipal migration. In Beira Interior (inland) emigration is normally higher than immigration, whereas in Beira Litoral (littoral), except for Baixo Mondego, immigration is higher than emigration (Fig. 6). At the moment the arrival of foreign immigrants is counteracting the migratory deficit in the sub-regions where this movement is taking place; however, as these immigrants are settling in the littoral zone, they are accentuating the alreadyexisting population differences. 


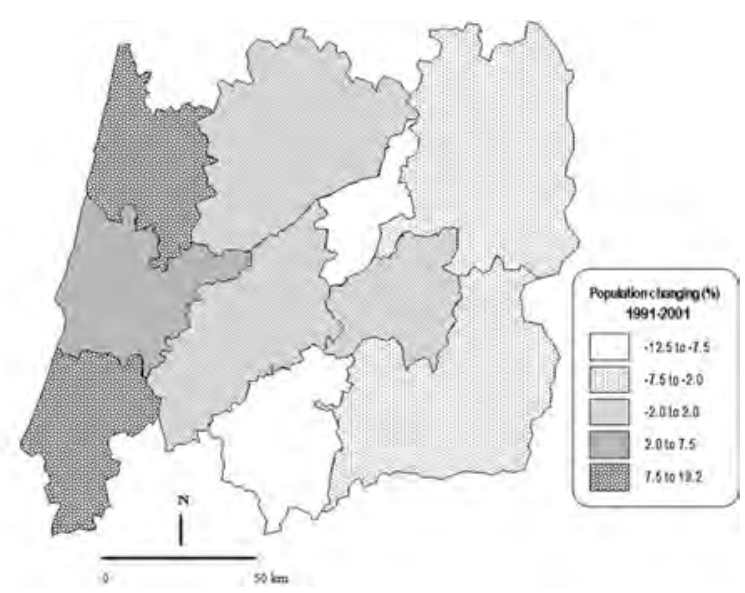

Fig.5 - Population change between 1991 and 2001 (Source: INE)

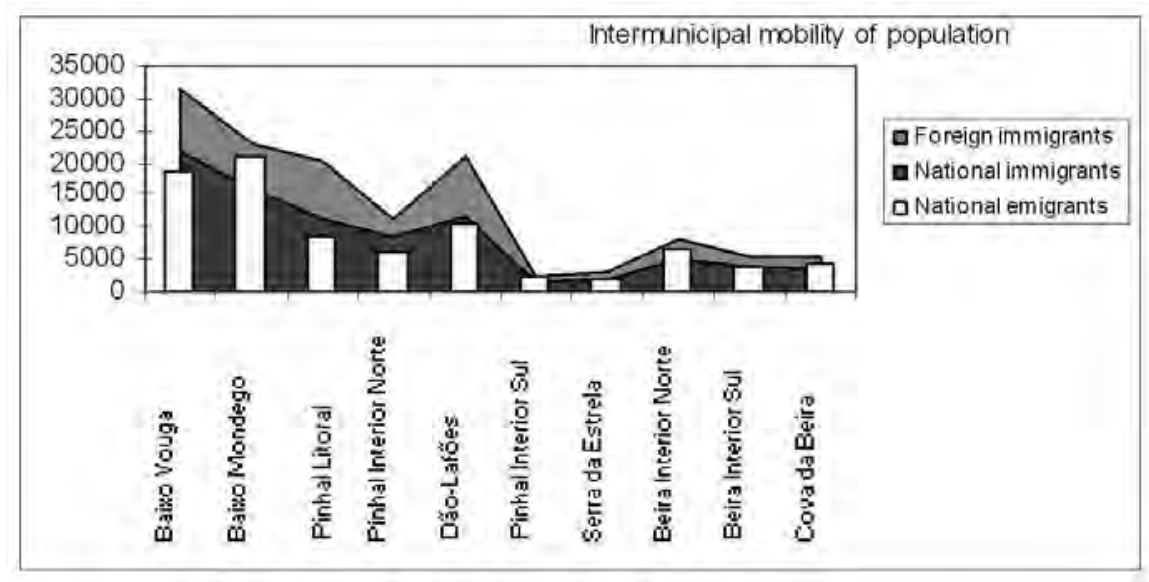

Fig. 6 - Intermunicipal population mobility (Source: INE)

\section{c) Population aging}

The population is aging throughout the region, but this phenomenon is more noticeable inland where the elderly predominate over the other age groups. This can be illustrated by comparing the age pyramids of Baixo Vouga (which represents the littoral sub-regions) and Beira Interior Sul (representing the other sub-regions). In the first, young adults are still predominant, whereas in the second, the age groups over 60 prevail (Fig. 7). 


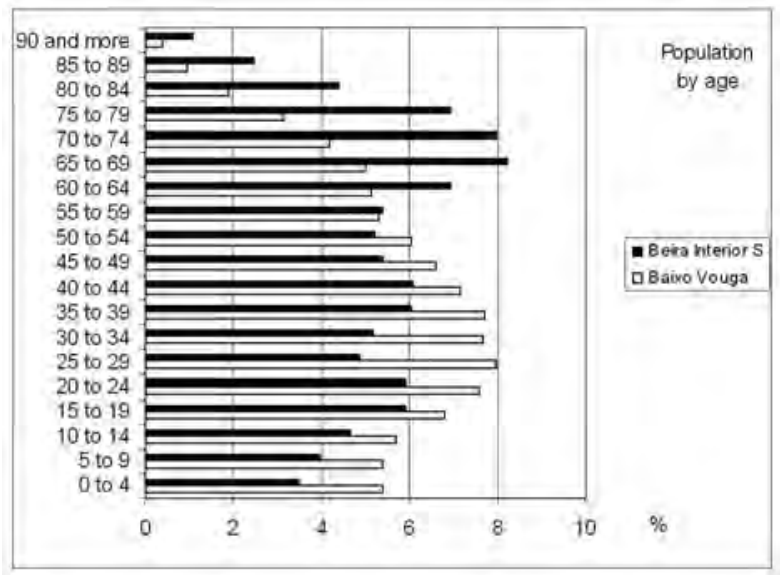

Fig. 7 - Population by age in Baixo Vouga and Beira Interior Sul (Source: INE)

The relation between the number of young people $(<15)$ and the elderly (> 64) is another indicator of this aging. Only in Baixo Vouga and Pinhal Litoral does the younger population still exceed the older population. In the other regions the number of old people is in some cases overwhelming. This aging process has been intensifying in the last few decades and there seems to be no sign of inversion (Fig. 8).

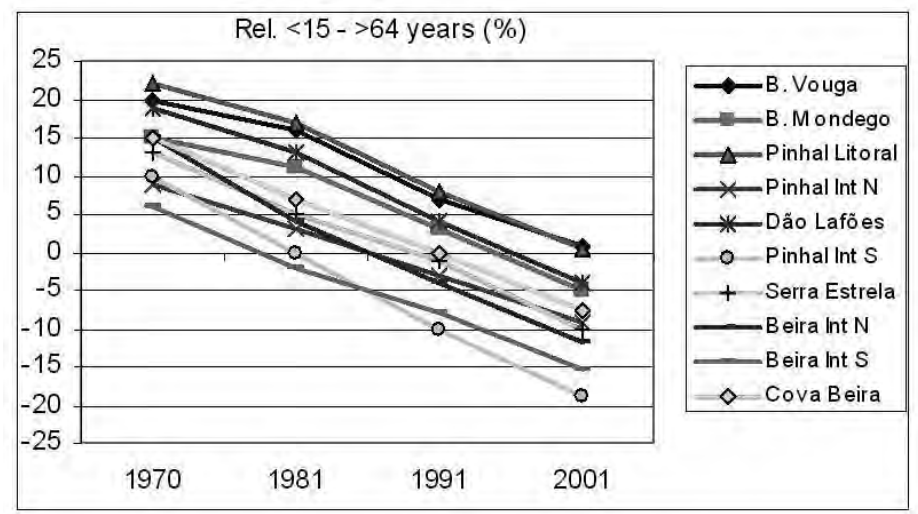

Fig. 8 - Relation between young people and the elderly (Source: INE) 


\section{d) Agricultural population}

The most negative features of the general population can be found in a more pronounced way among agricultural workers. If we analyse the age of single producers (the majority), we can easily see that in most sub-regions they are over 65 years old. In Beira Litoral and Pinhal Interior Sul, they represent more than 50\%. Only in Baixo Mondego, Baixo Vouga and DãoLafões is there a balance among the three age groups over 40 (Fig. 9).

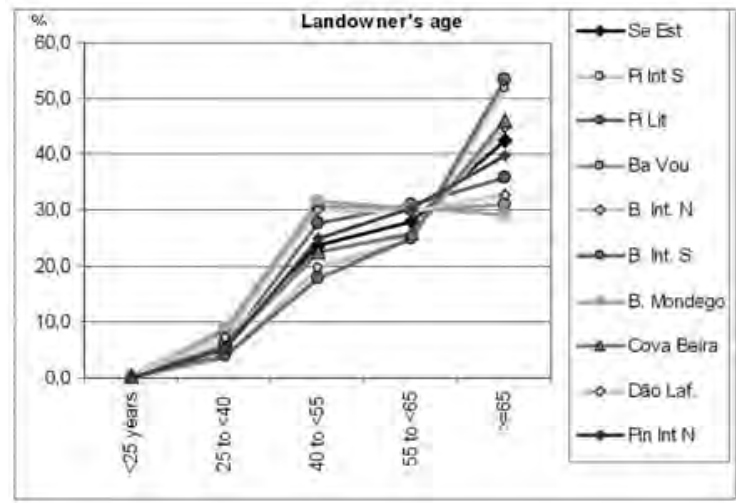

Fig. 9 - The age of individual farmers (Source: INE)

Another negative aspect is the very low literacy rate - most of these farmers only attended primary school and some of them are illiterate (almost $40 \%$ in Beira Interior) (Fig. 10).

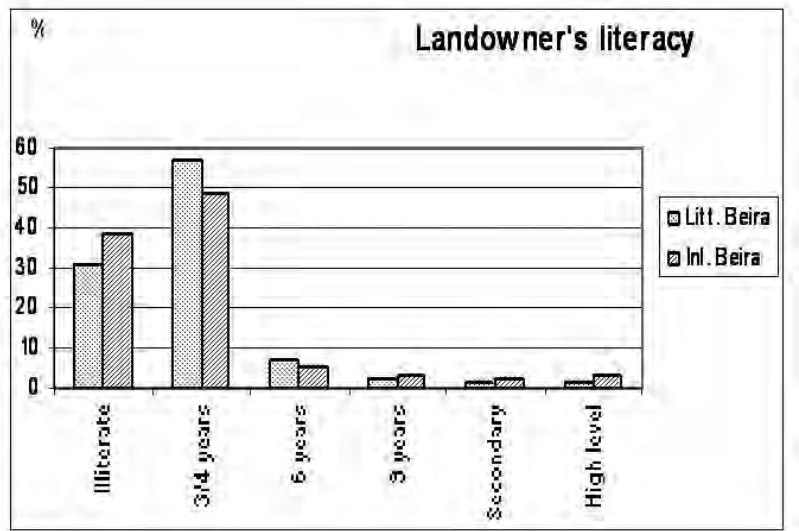

Fig. 10 - Landowner literacy in Littoral and Inland Beiras (Source: INE) 
Their technical knowledge is essentially empirical, since they have learnt farming techniques from older people and very few have studied agriculture at secondary or higher levels (Fig. 11).

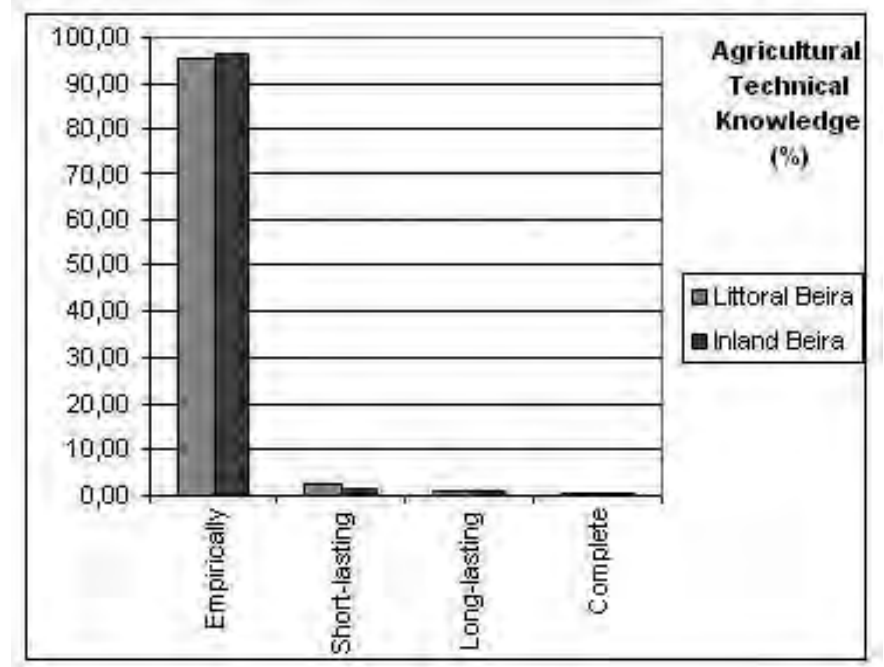

Fig. 11 - Agricultural technical knowledge (Source: INE)

\section{2 - Changes in land use}

\section{a) Decrease in cultivated area}

An expected consequence of the declining rural population was the abandonment of much of the land under cultivation. In 1989, however, in some inland sub-regions, there was an increase, probably due to Portugal's recent entry into the EU and the fact that some of the subsequent subsidies went to agriculture. In 1999 the decrease resumed (Fig. 12).

\section{b) Increase in meadowlands and permanent pastures}

As a response to the lack of labour in the fields and the inability of vegetable production to compete, the remaining farmers moved into extensive livestock rearing, increasing the number of meadows and permanent pastures (Fig. 13). The lack of manpower forces farmers to confine their livestock to fields by building fences. 


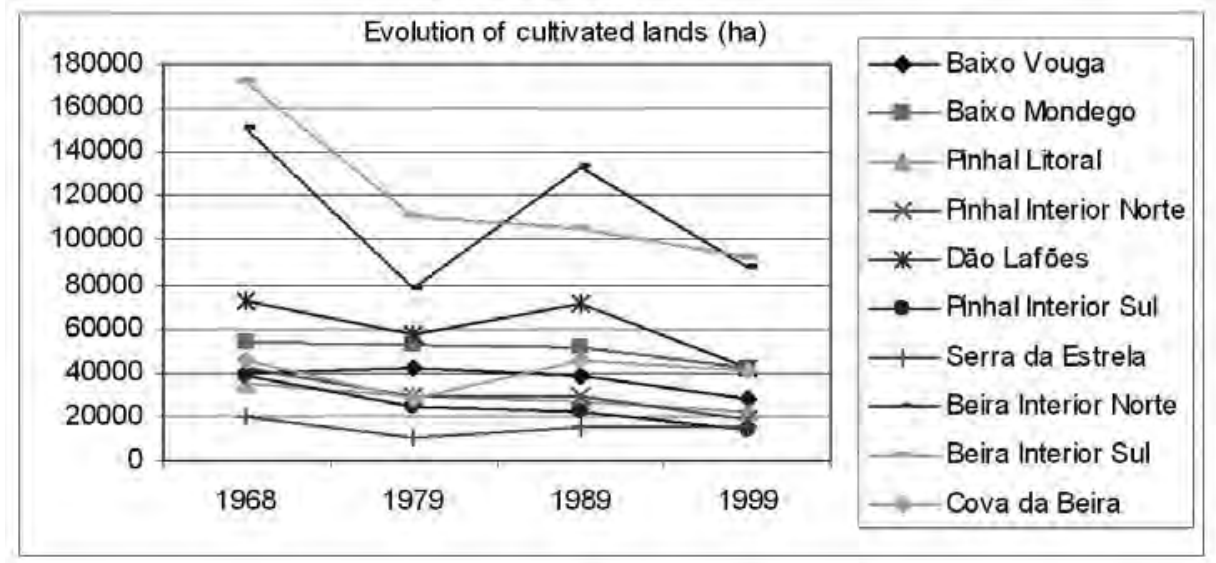

Fig. 12 - Cultivated land in the Central Region (Source: INE)

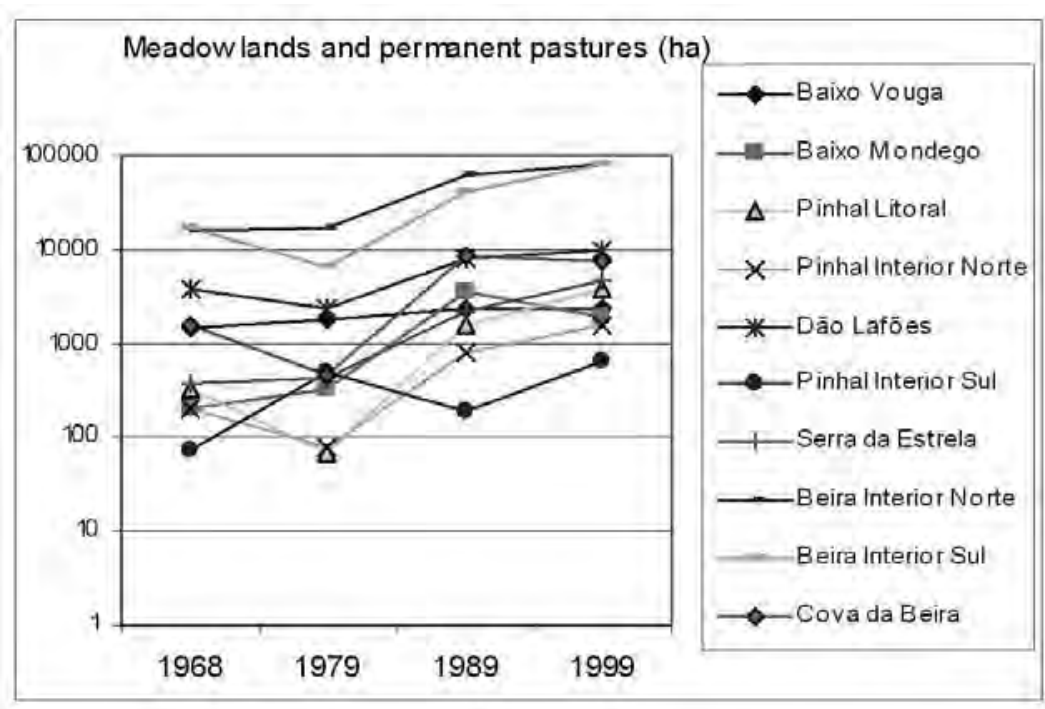

Fig. 13 - Meadowlands and permanent pastures in the Central Region (Source: INE)

\section{c) Forests and fires}

Absentee landowners with non-agricultural jobs, in particular, have used their former farmland for afforestation, often with species yielding highquality wood. 


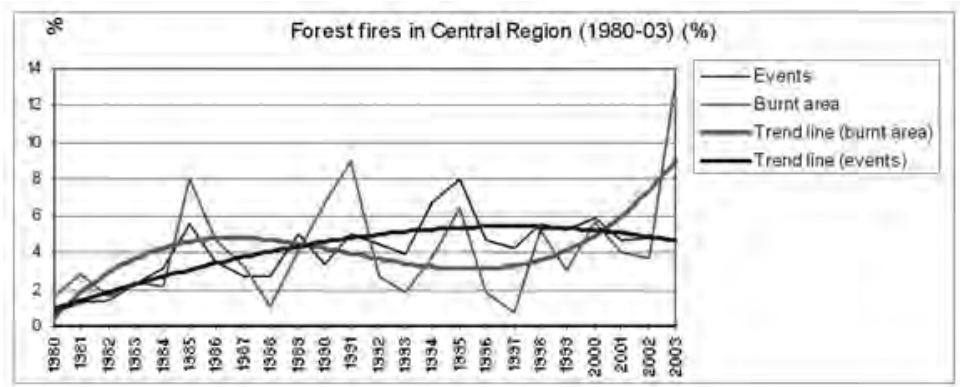

Fig. 14 - Forest fires in the Central Region (Source: DGF)

All over the region, but especially in areas where forests are more important, such as in the mountains, the frequency and intensity of forest fires have been changing both the landscape and the region's economy (Fig. 14). Studies carried out from 1980 to 2003 have shown an increase of burnt areas despite the improvement in terms of fire-fighting resources and the tendency for fires to diminish.

In little more than two decades some sub-regions emerged where the burnt area is either equal to or has surpassed the area of its land surface, as is the case of Serra da Estrela (Fig. 15). Just like this region, it is other mountainous sub-regions that present the highest percentages of burnt areas.

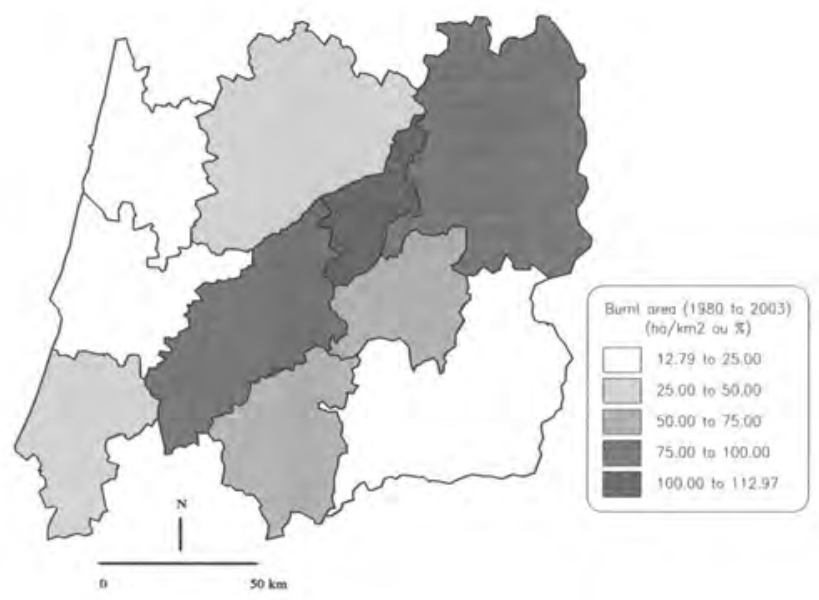

Fig. 15 - Burnt area in Central Region (1980-2003) (Source: DGF) 
3- Sample areas (Fig. 16)

\section{A. Mamodeiro}

Even though it is located in the more developed littoral zone near Aveiro, with a high population density and a low unemployment rate, there has been a significant reduction in the cultivated area. Much of it has been taken over by housing and industry or been afforested.

\section{B. Alvorge}

Due to the fact that it is located in the limestone hills of the littoral, this village is affected by its traditionally non-attractive geographical situation, because of scarcity of water. The significant fall in the number of people engaged in agriculture has led to its conspicuous abandonment.

\section{Ribeira de Cima}

It is a village set among mountains of schist, with over 100 inhabitants. The cultivated area has also decreased and has now been taken by forest or scrub, mostly because of frequent forest fires. In this adverse environment the smallest villages of the region are now deserted. 


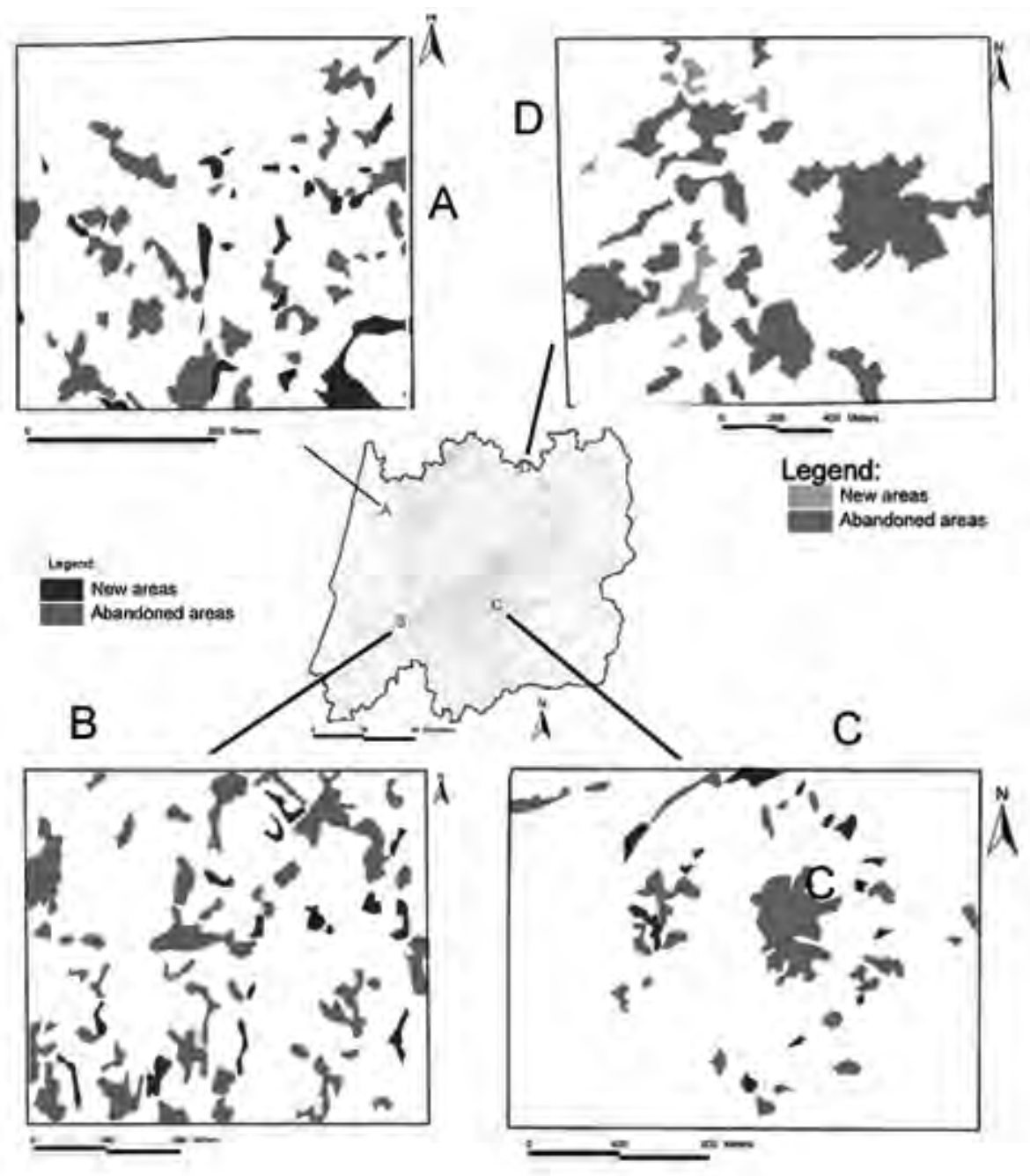

Fig. 16 - Sample areas chosen for analysis

\section{Pinheiro}

A typical village of the inland granite plateau. It is very isolated and its remaining population is elderly, it shows the highest level of abandonment of cultivated areas, which have been taken over by forest and especially by scrub. 


\section{4- Conclusion}

The four sample areas which have been chosen for this study, and if others had been chosen the results would not probably be very different, show that in the Centre Region of Portugal the fields are widely abandoned.

The indicators that have been presented (and many others could have been chosen) show that this region has undergone great social changes in recent decades. These changes are due to the substantial depopulation of the rural hinterland (which comprises all the sub-regions which are not by the sea) and the subsequent aging of the population, plus the fact that inhabitants of the littoral are not choosing agro forestry as their main activity. If the decrease in the number of farmers, which is also common in developed countries, had been followed by keeping the cultivated fields, improving the factors of production and thus increasing productivity, income and people's living standards, this radical transformation of the landscape would not have occurred, nor would the other secondary consequences (Baltazar, 2002).

The condition of "landscape gardener" currently enjoyed by the traditional or modern farmer is very unlikely to exist in the depopulated sub-regions, since the remaining population is not able to reverse the trend, either because of its age or because of its low standard of literacy. Only an injection of young people can attract people to the fields ${ }^{3}$. But these people need to be offered prospects of economic success and access to education and culture, at least in the nearest cities. Fortunately many of them can already offer these amenities through local universities and polytechnics. This economic success would also help to put an end to the idea that the rural worker is poor and illiterate. This idea has been taking many people away from this sector of the economy.

\footnotetext{
${ }^{3}$ It is interesting to see that in some inland cities and towns the resident population is increasing - in the last 20 years Guarda's population increased 9\% - while in other cities and towns in the same district the population decreased by an average of $10 \%$; in Viseu and Castelo Branco the same happened (Vieira, 2003). This is yet another indicator that people are leaving the fields.
} 
At present, when the European agriculture is mainly controlled by the countries where it is better developed and when agriculture is being abandoned by Portuguese governments, a change in this tendency is only a very remote possibility. The consequences, and speaking only in terms of the landscape, are too obvious: the abandonment of farming land leads to an increase in uncultivated areas, and these will slowly give way to their natural vegetation, first scrub and then woods (Figueiredo \& Aguiar, 2006), or be afforested. The continuum of forests and scrub associated with the ever-declining presence of people greatly increases the risk of forest fires, which will grow in intensity and scale, just as happened in 2003 and 2005. The probability of losing one of the sources of income of the rural populations in the short or long term - the forest - is very high, and those who still have some enthusiasm will definitely feel discouraged from continuing. The landscape will become monotonous through the loss of diversity and heterogeneity and more and more areas will show clear signs of deterioration of the soil because of erosion. We are therefore endangering our future and the future of our children.

If things continue the way they are, there is no doubt that the Centre Region of Portugal, especially the hinterland, will remain totally apart in terms of European patterns, even though a wide network of infrastructure has been built up over the last few decades, which has significantly improved overall accessibility to the region. It was thought at the time that this infrastructure would attract new investments, national and international, capable of bringing it out of its state of lethargy - we are still waiting for that to happen!

\section{References and statistical sources}

Baltazar, A. J. A. (2002) - Beira Interior Norte: população e povoamento numa região periférica. FLUC, Coimbra (Masters thesis).

Bertrand, G. (1978) - "Le paysage entre la nature et la société", Revue géographique des Pyrénées et du Sud-Ouest, 49, 2, pp. 239-258.

Figueiredo, A. \& Aguiar, C. (2006) - "Efeitos do abandono em áreas agrícolas marginais: reflexos na dinâmica da vegetação". Cadernos de Geografia (in press). 
Vieira, Pedro A. (2003) - O estrago da nação, Lisboa, Dom Quixote, Cadernos DQ Reportagem 01. INE (Instituto Nacional de Estatística) (1970) - 11 Recenseamento da População.

INE (1981) - Recenseamento da População e da Habitação.

INE (1991) - Censos 91. XIII Recenseamento Geral da População.

INE (2001) - Censos 2001. XIV Recenseamento Geral da População.

INE (1968) - Inquérito às Explorações Agrícolas do Continente. Região Centro.

INE (1979) - Recenseamento Agrícola.

INE (1989) - Recenseamento Geral Agrícola.

INE (1999) - Recenseamento Geral da Agricultura. Região Centro. 